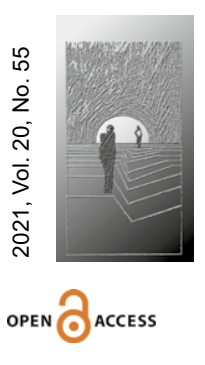

\title{
Edukacja zintegrowana w dobie jakościowego kryzysu dydaktycznego
}

\section{STRESZCZENIE}

CEL NAUKOWY: Próba oceny przejawiającego się w edukacji zintegrowanej kryzysu dydaktycznego - jakościowego, mającego miejsce w typowej szkole na tradycyjnych zajęciach z dziećmi w klasach I-III.

PROBLEM I METODY BADAWCZE: W artykule analizom krytycznym poddano złożoność, niejasności i bariery realizacji przez nauczycieli koncepcji integracji w praktykach społecznych pod kątem jakościowym. Zastosowano metodę opisowo-eksplanacyjno-interpretacyjną.

PROCES WYWODU: Zaprezentowano kluczowe znaczenie wczesnej edukacji dziecka pod kątem jakości kształcenia istniejącego stanu faktycznego w szkołach.

WYNIKI ANALIZY NAUKOWEJ: Wskazanie jakościowych strategii wspierania całościowego rozwoju dziecka.

WNIOSKI, INNOWACJE, REKOMENDACJE: Metamorfoza sposobu nauczania - uczenia się, poszukiwanie tropów „inności” konstruktywistycznej.

\section{$\rightarrow$ SŁOWA KLUCZOWE: EDUKACJA ZINTEGROWANA, UCZEŃ, NAUCZYCIEL, KRYZYS DYDAKTYCZNY, JAKOŚĆ NAUCZANIA}

\begin{abstract}
Integrated Education in the Age of Qualitative Didactic Crisis

RESEARCH OBJECTIVE: An attempt to assess the didactic-qualitative crisis manifested in integrated education, taking place in a typical school during traditional classes with children in grades 1-3.
\end{abstract}

THE RESEARCH PROBLEM AND METHODS: In the presented article, qualitative - critical analysis covered the complexity, ambiguities and barriers to the implementation of the concept of integration in social practices by teachers The descriptive-explanatory-interpretative method was used. 


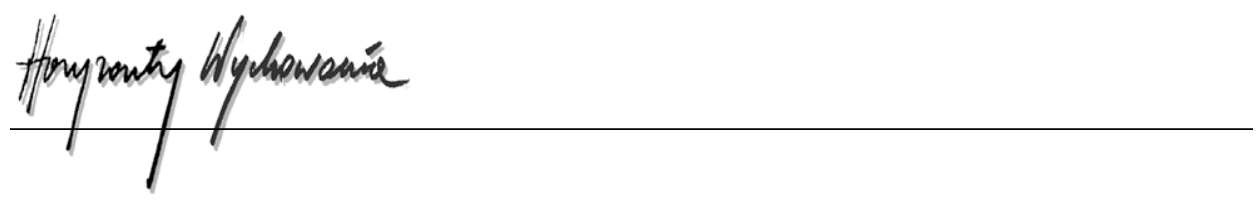

THE PROCESS OF ARGUMENTATION: The key importance of early childhood education was presented in terms of the quality of education in the actually existing state in schools.

RESEARCH RESULTS: Indication of qualitative strategies supporting holistic development of the child.

CONCLUSIONS, INNOVATIONS, AND RECOMMENDATIONS: Metamorphosis of the way of teaching - learning, searching for traces of constructivist "otherness."

$\rightarrow$ KEYWORDS: INTEGRATED EDUCATION, STUDENT, TEACHER, DIDACTIC CRISIS, QUALITY OF TEACHING

\section{Wstęp}

Mijają 22 lata od momentu wprowadzenia koncepcji integracji do szkół, która boryka się z wieloma trudnościami: metodycznymi, merytorycznymi i organizacyjnymi. Tkwi w stanie „rezyduum” pod kątem jakości nauczania (badania empiryczne: Sowińska, Gruszczyk-Kolczyńska, Jakowicka, Michalak, Marek, Karbowniczek, Misiorna, Klus-Stańska, Dabrowski, Dylak, Filipiak, Nowak-Łojewska, Zalewska, Kopaczyńska, Kruk, Nowak, Żytko i in.). W kontekście niniejszych rozważań zaprezentowanych poniżej, rezyduum rozumiane jest jako narzędzie analityczne, odnoszące się do tego, co stanowi resztę, pozostałość po tak szeroko rozumianej koncepcji. Integracja często występuje już śladowo jako typowa „cząstka” procesu, w którym uczeń samodzielnie myśli i aktywnie uczestniczy w budowaniu tożsamości oraz osobistej wiedzy, poznaje świat „po swojemu", nabywa upodmiotowionych kompetencji, które dla niego czynią świat oswajalnym, koherentnym, zrozumiałym, zapewniającym poczucie kontroli poznawczej; jako resztka procesów kulturowo-społecznych i aksjologicznych. Należy zgodzić się ze stwierdzeniem D. Klus-Stańskiej (2015, s. 28), że idea integracji należy do najbardziej mglistych koncepcji realizowanych w polskiej szkole, wszystko obsesyjnie nazywa się integracją, nawet to, co nią nie jest. Widoczne jest istnienie w pozorowanej zmianie, uwięzienie edukacji zintegrowanej w systemie klasowo-lekcyjnym, bagatelizacja jej rzeczywistych założeń w praktykach społecznych, brak dbałości o „nową” jakość kształcenia, preferowanie teorii urabiania, coraz głębsze wchodzenie w głąb pustyni aksjologicznej, w model sztywnej transmisji kulturowej oraz w monistyczną wersję postrzegania świata. Jakość w prezentowanych refleksjach przedstawiona została jako akt rozwoju zasobów poznawczych, emocjonalnych, społecznych i kompetencyjnych uczniów, jako akt rozwoju tożsamości i rewitalizacji kultury, jako edukacja dla ucznia uwzględniająca jego funkcjonowanie, specyfikę psychospołeczną, zainteresowania i preferencje. 


\section{Edukacja zintegrowana - zadania, wątpliwości, pozory realizacji w praktyce edukacyjnej}

Edukacja zintegrowana to ogólna refleksja nad wiedzą o uczeniu, rewolucjonizuje to uczenie i wszystkie obszary ludzkiego życia. Nie należy jej traktować jako intelektualnej „taśmy produkcyjnej”, z której wychodzi wyuczony i znormalizowany według kanonów treści programowych produkt ludzki (Gnitecki, 1996). To tworzenie dynamicznych przekształceń struktur poznawczych i obrazowania językowego w wyniku zastosowania zintegrowanych zadań szkolnych w warunkach relaksacji, wizualizacji i afirmacji. W procesie kształcenia eksponujemy przede wszystkim poznawanie przez dzieci zróżnicowanych znaków językowych, umożliwiających zarówno percepcję określonych fragmentów rzeczywistości, jak i przekazywanie efektu poznania w ramach kontaktów społecznych. W holistycznym podejściu do ucznia kładzie się nacisk na jego duchowość i życie wewnętrzne, wyzwala się potencjał do przekształcania świata, a przemiana osobowa, społeczna i globalna jest warunkiem do tworzenia się nowych relacji między ludźmi. Uczenie się holistyczne obejmuje dwa połączone ze sobą procesy składowe: bezpośrednich i pośrednich interakcji oraz wewnętrzny proces psychiczny przyswajania wiedzy. Nauczyciele klas początkowych powinni posiadać wnikliwą wiedzę i dogłębne kompetencje ku integracji, jej idei, płaszczyznom, kontekstom, aby móc wdrażać ją do praktyki edukacyjnej. Każda konstruktywnie uprawiana edukacja ma odsłaniać głębszy sens i znaczenie tworzenia całości, bowiem w tym procesie tkwi wielka wartość edukacyjna. Edukacja zintegrowana to edukacja do globalnego przetrwania i rozwoju.

W praktyce szkolnej podejście do integracji, jak słusznie zauważa A. Nowak-Łojewska (2007, s. 12, 37), zdominowane jest jedną koncepcją realizacyjną, którą stanowią cykle metodyczne, dłuższe jednostki czasowe obejmujące ciągłość tematyczną z realizacją różnych obszarów edukacyjnych, takich jak: edukacja polonistyczna, matematyczna, przyrodnicza, plastyczna, muzyczna itd. W związku z tym zawężone zostało podejście do integracji, bez ukazywania nauczycielowi ciągłej otwartości realizacji na nowe rozwiązania, na potrzebę poszukiwania różnorodnych ujęć, koncepcji praktycznej o różnej osi integracyjnej. Pozorów integracji dopatruje się także D. Klus-Stańska (2005, s. 188-192, 224) w zbliżonej reprodukcji tego, co już zostało zrobione przez nauczycieli, w określeniu „blok tematyczny”, które uważa za jałowe pedagogiczne. Wskazuje na różnice między konotacjami terminów: „temat” i „problem”, twierdząc, że skupianie treści wokół problemu ma swoją pozaadministracyjną logikę. Wynika z rodzaju zagadnienia, z jego struktury (problemowej) i naturalnych (niezależnych od szkoły) wewnętrznych złożonych relacji, natomiast temat blokowy kompiluje różne treści z różnych dziedzin wiedzy tylko poprzez zapis w dzienniku i scenariuszu zajęć dla celów administracyjno-kontrolnych. Każde z tych podejść pociąga za sobą określone konsekwencje poznawcze, organizacyjne i dydaktyczne, łączenie wszystkiego ze wszystkim: celów, treści, metod, form, ofert edukacyjnych, środowisk życia, wszystkich podmiotów edukacji. 


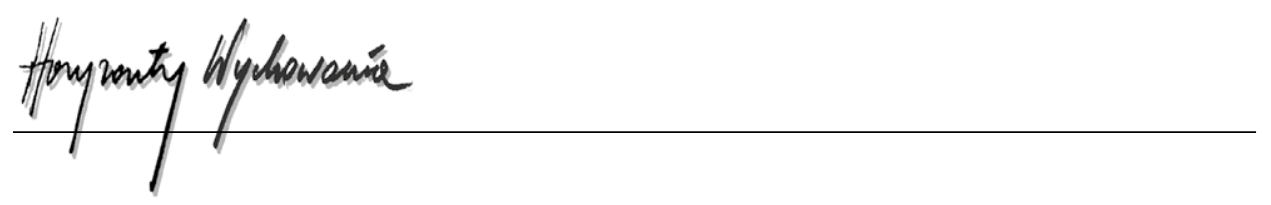

\section{Jakość edukacyjna i jej kryzys palącym problemem edukacji} zintegrowanej, poszukiwanie tropów „inności” działań

Mówiąc o kryzysie dydaktycznym jakościowym, ujmuję go jako palący problem dotykający pedagogikę wczesnoszkolną jako subdyscyplinę nauk pedagogicznych oraz zintegrowaną edukację wczesnoszkolną jako pracę dydaktyczno-wychowawczą z dzieckiem w młodszym wieku szkolnym. Palący to taki, który wymaga natychmiastowej metamorfozy, modyfikacji i podjęcia szybkich działań edukacyjnych oraz innowacyjnych rozwiązań dydaktyczno-wychowawczych. Jakość oraz inność jako wielowarstwowe struktury moim zdaniem decydują o ukierunkowaniu edukacji na nurt konstruktywistyczny, humanistyczny, libertariański, emancypacyjny, krytyczny, na wszechstronną twórczość uczniów, wybór kształcenia respektującego epistemologiczną psychologię głębi umysłowych, dobór intrygujących zadań i ćwiczeń rozwojowych, o ontologicznym, antropologicznym i aksjologicznym „byciu” uczniem, o wprowadzeniu w dialog i wielokierunkową komunikację. Za priorytetowe uważam stopniowe nabywanie poczucia sprawstwa, czyli przeświadczenia o możliwościach aktywnego wpływania na własne losy, rzeczywistość i uczenie się. Mając na względzie konstruktywistyczną jakość nauczania w polskiej szkole, możemy skierować uwagę nauczyciela na: „założenia filozoficzne, psychologiczne i socjologiczne, tworzące fundament modelu kształcenia, opartego na prymacie całości - opozycyjnego wobec podejścia asocjacyjnego i atomistycznego" (Zalewska, 2003, s. 97), integrację ujmowaną jako odpowiedź na specyfikę rozwojową dzieci i holistyczne postrzeganie przez nie rzeczywistości, nowy kontekst i nowe wymogi dla systemu szkolnego w klasach I-III, dotyczące: rekonstrukcji stosowanych metod słownych, podających, służących przyswajaniu wiedzy, rekonstrukcji przestrzeni i organizacji wszechstronnego środowiska uczenia się, rekonstrukcji przygotowania, kompetencji kadry, rekonstrukcji celów i zadań szkoły, zbudowanych w nowej racjonalności (Klus-Stańska, 2015, s. 40-41), począwszy od alfabetyzacji wizualnej, poprzez alfabetyzację krytyczną (Kwieciński, 2007), samorządność i podmiotowość jako przeciwieństwo szkoły całkowicie podlegającej polityce państwa, indywidualizację kształcenia wielostronnego, gromadzenia, stosowania paradygmatu konektywistycznego. O jakości pracy nauczyciela świadczą: interdyscyplinarne wsparcie w odkrywaniu przez uczniów tajników wiedzy, poszerzanie ich horyzontów myślowych, umiejętność budowania konstruktywnej kompatybilności między teorią i praktyką, projektowanie takiej pedagogiki, która w centrum stawia troskę o wielointeligentny rozwój dzieci, wprowadza ich w kulturę, tworzy środowisko do wzrastania w społeczeństwo, otwiera i rozwija dla pedagogiki perspektywy jakościowego myślenia o nauczaniu dzieci. Warto w tym miejscu zwrócić uwagę na troskę o elastyczne relacje podmiotowe i wielki potencjał osobowy uczniów, dążenie do realizacji swoich pasji, umacnianie poczucia wartości poprzez sprawczość, adekwatność i doświadczenie autonomii w twórczym oraz wielokierunkowym działaniu (Karbowniczek i Kucharska, 2021). Do kolejnych poszukiwań należą: wrastanie w treści symboliczne kultury - jej dzieła i język, swobodę, wieloświatopoglądowość, podejmowanie wyzwań cywilizacyjnych, pozytywne przekształcanie środowiska uczenia się, 
gotowość nauczyciela do krytycznej samooceny, reagowanie na sygnały i potrzeby społeczne, zielone światło na inicjatywy i oryginalne pomysły dziecięce, wyrównywanie startu i szans edukacyjnych uczniów, stosowanie paradygmatu wspólnoty i partycypacji. Pogłębiona refleksja nad jakością nauczania skierowana jest szczególnie w proces rozwijania kompetencji wiedzy ucznia i nauczyciela, wyznaczających zasięg myślenia, rozumienia, interpretacji oraz konstruowania siebie i rzeczywistości dookoła. Wiedza wypracowana w tym zakresie może uczestniczyć w implementacji jakościowych zmian zachodzących w szkole, klasie, uczniu, nauczycielu, zatem w przestrzeni edukacyjnej, społecznej i kulturowej. Kompetentny nauczyciel zna dokładnie cel, do którego zamierza poprowadzić ucznia, strukturę i hierarchię wartości, dysponuje „kompasem ideowym”, pozwalającym mu wznieść się ponad trudności otaczającej rzeczywistości. Traktuje go jako byt autonomiczny, żyjący w przestrzeni wolności, jako kreatora własnej przyszłości, wprowadza dziecko w świat dialogu w horyzoncie wartości, krąży wokół tych wartości, wraz z dzieckiem wzajemnie się nimi obdarowując. Uczy prowadzenia dialogu z drugim jako przebudzenia możliwości odkrywania samego siebie. Tropi wątki alternatywne, stwarzając korzystny klimat do formułowania własnych koncepcji w celu zbudowania mikrosystemów edukacyjnych. Prezentuje bogactwo oryginalnych pomysłów na inną szkołę niż tradycyjna oraz wieloparadygmatyczne sposoby myślenia o edukacji. Dba o wprowadzenie ucznia w stan „actio” (siła sprawcza, jego aktywny i twórczy wkład w tworzenie rzeczywistości), ujmuje myślenie jako dźwignię kreatywności, a logikę jako strażnika myśli. Dbając o jakość edukacyjną, włącza się w linię działania dziecka, a dziecko w linię działania nauczyciela. Obopólnie konstruują linię działania. Wychowanek w aktywny sposób tworzy swój wewnętrzny świat, a wychowawca szanuje ten świat, umie wejść w "głębię" dziecka i razem rozwijać to, co nowe, tworzyć zalążki przyszłej wiedzy i przyszłych umiejętności. Edukacja zintegrowana pod względem jakościowym powinna przygotowywać ucznia do zmian zachodzących w świecie, do zmiany schematów jego działań, opierać się na czynnościach permanentnie oryginalnych, twórczych i niepowtarzalnych, na wykreowaniu istoty autonomicznej, otwartej na środowisko, wielostronnie rozwijającej się.

Proces uczenia to uczenie się przeżyciowe, całym sobą, „trzewne” w odróżnieniu od uczenia się powierzchownego, częściowego, angażującego ucznia "od szyi w górę" (Rogers, 1983). Najskuteczniejszym sposobem uczenia się w klasach I-III jest uczenie się w działaniu poprzez związek z doświadczeniem poszukującym, wzajemną wymianę doświadczeń i ich poszerzanie. Uczniowie chcą odkrywać swój świat, przez pryzmat którego postrzegają siebie jako jego część (Illeris, 2006). Nauczyciel przyjmuje rolę przewodnika, koordynatora w otwartym i jakościowo szerokim procesie edukacyjnym. Pomaga i wspiera uczniów w samodzielnym nabywaniu wiedzy. Jego działalność polega na autokreacji, czyli twórczym stworzeniu własnego wizerunku. W kontekście jakościowym współczesny nauczyciel to refleksyjny praktyk, kreujący „krytyczne” dziecko, rozwijający jego potencjał, wiedzę, umiejętności, sposoby wyrażania siebie, stwarzający możliwości doświadczania, kształtowania pracowitości, indywidualności uczenia się w nowym znaczeniu „refleksyjności” jako możliwości odniesienia się do własnego rozumienia siebie 


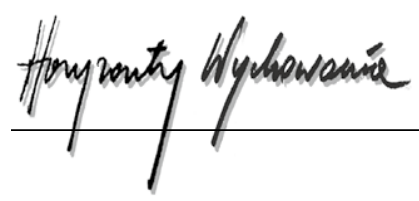

i znaczenia, jakie przypisujemy wpływom, których doświadczamy. Jego kompetencje i wiedza oraz nowoczesność, w której naucza, wyznaczana jest przez ciągły „niedosyt" - apetyt na nowość. Owa nowoczesność, jak słusznie zauważa A. Giddens (1990, s. 39), konstytuuje się w interdyscyplinarnie stosowanej wiedzy przez nauczyciela i poprzez nią. Refleksyjność jest nie tylko fenomenem intelektualnym, ale w dużym stopniu odnosi się do emocji, doświadczeń, samorozumienia i budowania tożsamości. W sytuacji uczenia się zarówno rozwój osobowy, jak i refleksyjność stają w obliczu osiągnięcia określonych jakości, co dla każdego jest wyzwaniem. Dlatego oba procesy wymagają ogromnego wysiłku osobistego, poprzedzonego znaczącą motywacją. Tropy poszukiwań jakościowych dotyczą także przestrzeni, w której zachodzi uczenie się oraz ramy tworzenia inspirujących do działań sytuacji edukacyjnych. W głębię koncepcji uczenia się sytuacyjnego wprowadzają nas J. Lave i E. Wenger (1991), których zdaniem każde uczenie się zachodzi w specyficznej sytuacji, szczególnie znaczącej dla natury uczenia się i jego wyników. Dzięki niej formułuje się twierdzenia o relacyjnym charakterze wiedzy i uczenia się o negocjacyjnym charakterze znaczeń i o dylematotwórczej naturze aktywności poznawczej osób uczących się. Taka perspektywa oznacza sytuacyjny charakter każdej dziecięcej aktywności. Poszczególne typy i treści zróżnicowanych sytuacji mają pewne szczególne jakości edukacyjne, np. transformacyjne odtworzenie powiązań między teoretycznymi stanowiskami, restrukturalizację wiedzy z uwzględnieniem różnych celów, uogólnienie określonego zakresu treści kształcenia i podsumowanie go, specyfikację wiedzy ogólnej i jej wdrożenie, samoidentyfikację mechanizmu działania praw i wzorców pedagogicznych, wdrożenie sposobów zastosowania zdobytej wiedzy w podobnych sytuacjach, poszukiwanie odpowiedzi na postawione pytania. Kolejnym elementem wpływającym na jakość kształcenia jest uczenie się kolektywne w kolektywnej przestrzeni. Nowe i ekspansywne wzorce myślenia są nauczane tam, gdzie kolektywne aspiracje wykazują wolność, a dzieci uczą się, jak uczyć się razem. H.S. Olesen (1989) doświadczenie uważa za proces kolektywny. Jego zdaniem koncepcja doświadczenia jest aktywna, kreatywna, kreuje koherencję, ale także krytyczna i negocjacyjna. Organizacja uczących się uczniów to zdolność do kreowania kooperatywnych zmian. Uczenie się we współpracy to z kolei „uczenie się wspólnie z innymi”, może ono obejmować naukę w parach, jak i uczenie się w grupach. Towarzyszą temu zwykle dyskusje, rozwiązywanie problemów, wykonywanie poleceń itp. Uczniowie w grupie wspólnie realizują powierzone im zadania w sposób zorganizowany, mający na celu wspomaganie innych jej członków. Edukacyjna aktywność grupowa uczniów jest celową czynnością, mającą charakter pokonywania trudności dla osiągnięcia określonego efektu, społecznie użytecznego. Lista wartościowych pod względem jakościowym rozwiązań jest nieskończona i otwarta. W niniejszych rozważaniach oraz interpretacjach wskazałam na te, które moim zdaniem są najważniejsze. 


\section{Wnioski}

Grożąca trywializacja, rozpad wiedzy, dezintegracja, inercja w podejmowaniu sensowych działań edukacyjnych oraz ideologiczne parcie w stronę zapewnienia władzy dorosłym nad dziećmi, nad ich rozwojem, tożsamością, horyzontem świata, którego są uczestnikami, słabe spełnianie deklarowanych zadań przez instytucje oświatowe, a przede wszystkim jednoprojektowość myślenia, powielanie wzorów, awersja do nowatorskich rozwiązań oraz wygodność i bezpieczeństwo w stosowaniu stereotypów stanowią tylko nieliczne czynniki oddziałujące na „nijakość” czy też „bylejakość” uprawiania edukacji zintegrowanej. Na uwagę zasługują jeszcze bardziej blokująca wielointeligentny rozwój dziecka sztywność metodyczna, zamykająca otwartą dziecięcą wizję na nową rzeczywistość, wizję opartą na wykreowaniu jednostki samodzielnie myślącej, dialogowej, pytającej, decyzyjnej, negocjującej znaczenia. W pracy dydaktyczno-wychowawczej nauczyciela organizacja edukacji zintegrowanej, formułowanie i realizacja celów, integracja treści z poszczególnych obszarów edukacyjnych, dobór metod, form pracy, regulowanie czasu trwania zajęć są dalekie od rzeczywistych założeń wdrożonej koncepcji. Jest ona pozbawiona spójności, sporadyczna i ignorowana. Przyjmuje charakter sztucznego i nierzetelnego łączenia dziedzin edukacji, a same warunki niezbędne do realizacji tej koncepcji są niewystarczające.

\section{BIBLIOGRAFIA}

Giddens, A. (1990). The consequences of modernity. Stanford University Press.

Gnitecki, J. (1996). Teoria zintegrowanych zadań szkolnych. Wydawnictwo Naukowe PTP. Oddział w Poznaniu.

Illeris, K. (2006). Trzy wymiary uczenia się: poznawcze, emocjonalne i społeczne ramy współczesnej teorii uczenia się (A. Jurgiel, tłum). Wydawnictwo Naukowe Dolnośląskiej Szkoły Wyższej Edukacji TWP.

Karbowniczek, J. i Kucharska, B. (2021), W poszukiwaniu nowej jakości edukacji wczesnoszkolnej podejście paradygmatyczne i swoiste (re)interpretacje. W: H. Bejger, O. Lisovets i S. Borysyuk, Aktualne problemy społeczne Ukrainy i Polski. Aspekty edukacyjne i socjokulturowe (s. 10-23). Państwowa Wyższa Szkoła Zawodowa w Chełmie, Chełmskie Towarzystwo Naukowe.

Klus-Stańska, D., (2005). Pozory integracji. W: D. Klus-Stańska i M. Nowicka, Sensy i bezsensy edukacji wczesnoszkolnej (s. 188-192). Wydawnictwa Szkolne i Pedagogiczne.

Klus-Stańska, D. (2015). Dezintegracja tożsamości i wiedzy jako proces i efekt edukacji wczesnoszkolnej. W: D. Klus-Stańska (red.), (Anty)edukacja wczesnoszkolna (s. 24-57). Oficyna Wydawnicza "Impuls".

Kwieciński, Z. (2007). Potrzeba alfabetyzacji krytycznej. W: J. Rutkowiak, D. Kubinowski i M. Nowak (red.), Edukacja, moralność, sfera publiczna. Materiały z VI Ogólnopolskiego Zjazdu Pedagogicznego PTP (s. 397-407). Oficyna Wydawnicza „Verba”.

Lave, J. i Wenger, E. (1991). Situated learning: legitimate peripheral participation. Cambridge University Press.

Nowak-Łojewska, A. (2007). Wprowadzenie. W: I. Kopaczyńska i A. Nowak-Łojewska, Wymiary edukacji zintegrowanej (s. 4-9). Oficyna Wydawnicza "Impuls”. 


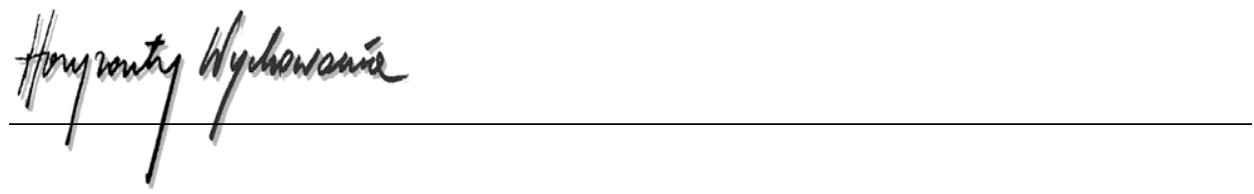

Olesen, H.S. (1989). Adult education and everyday life. Roskilde University.

Rogers, C. (1983). Freedom to learn for the 80's. Merrill Pub Co.

Zalewska, E. (2003). Teoretyczne konteksty nauczania zintegrowanego - rekonstrukcja przez powrót do źródeł. W: D. Klus-Stańska, M.S. Szymański i M.J. Szymański, Renesans(?) nauczania całościowego. Współczesna dydaktyka wobec nauczania zintegrowanego, blokowego i przedmiotowego (s. 97-112). „Żak”.

\section{Copyright and License}

This article is published under the terms of the Creative Commons Attribution - NoDerivs (CC BY- ND 4.0) License http://creativecommons.org/licenses/by-nd/4.0/ 